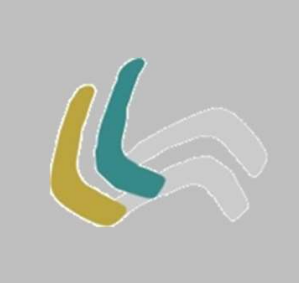

\title{
HISTÓRIA E MEMÓRIA EM \\ O OUTONO DO PATRIARCA DE GABRIEL GARCÍA MÁRQUEZ ${ }^{1}$
}

\section{HISTORY AND MEMORY IN THE AUTUMN OF THE PATRIARCH BY GABRIEL GARCÍA MÁRQUEZ}

\author{
Michelle Márcia Cobra Torre² \\ Universidade Federal de Minas Gerais
}

\begin{abstract}
Resumo: $\mathrm{O}$ artigo propõe discutir as relações entre história e memória no romance $O$ outono do patriarca, do escritor colombiano Gabriel García Márquez, publicado em 1975. Parte-se de uma discussão baseada em textos teóricos sobre memória e história, de pensadores como Paul Ricoeur, Michael Pollak, Hugo Achugar e Jacques Le Goff. O estudo enfoca como o patriarca, personagem do romance, forja uma memória oficial para o país que domina, e como, com a morte do ditador, outros relatos, que foram marginalizados e silenciados pela história oficial do governo, surgem na cena pública construindo outras histórias da pátria. Ressalte-se que o artigo aborda as relações da história com a literatura, no que se refere à ditadura e ao personagem patriarca do romance, bem como aborda as disputas pela memória e o desnudamento da narrativa histórica oficial, que justificava o poder absoluto do patriarca.
\end{abstract}

Palavras-Chave: O outono do patriarca; García Márquez; Memória; História.

1 Este artigo tem como ponto de partida as reflexões iniciadas na dissertação de Mestrado em Estudos Literários, intitulada Transculturação e dialogismo/pátria, nação e memória em O outono do patriarca, defendida na Universidade Federal de Minas Gerais, em 2011.

2 Endereço eletrônico: michelletorre@yahoo.com.br. 
Abstract: The article proposes to discuss the relationship between history and memory in the novel The Autumn of the Patriarch, by Colombian writer Gabriel García Márquez, published in 1975. It starts with a discussion based on theoretical texts on memory and history, by thinkers such as Paul Ricoeur, Michael Pollak, Hugo Achugar and Jacques Le Goff. The study focuses as the patriarch, character of the novel, builds the official memory for the nation under your domain, and how, after the death of the dictator, different reports, marginalized and silenced by the official history create by the government, appear on the public scene building other stories of the motherland. The investigation discusses the relations between history and literature in what it refers to the dictatorship and to the character patriarch, as well as the disputes over memory and the revelation of the official historical narrative that justified the absolute power of the patriarch.

Keywords: The autumn of the patriarch; García Márquez; Memory; History.

\section{INTRODUÇÃO}

História e literatura podem propor novas leituras sobre o passado, abordando discursos ou personagens marginalizados pelas vertentes historiográficas hegemônicas. Nessa perspectiva, ambas se relacionam com a memória e o esquecimento. Novas abordagens históricas podem servir de inspiração para a literatura, bem como a literatura, ao trabalhar elementos de uma história silenciada ou marginalizada, pode promover o interesse e o aprofundamento dos estudos históricos.

Ao se valerem da memória, história e literatura abrem a possibilidade para a manutenção ou o esquecimento, bem como ajudam a forjar ou a transformar imaginários e identidades. Essa questão se relaciona com a memória coletiva seja de um grupo, seja de um país. Importa ressaltar que os "usos e abusos" da memória e do esquecimento, por grupos detentores de poder, levam à marginalização de memórias e ao despojamento da capacidade de sujeitos narrarem suas histórias.

Nessa perspectiva, este artigo se propõe a refletir sobre o romance O outono do patriarca do escritor colombiano Gabriel García Márquez, publicado em 1975. A obra de ficção dialoga com os regimes ditatoriais vividos pela América Latina, 
com suas políticas e ditadores autoritários e violentos. Serão abordadas as relações estabelecidas na obra entre a memória e o esquecimento.

O contexto de produção de O outono do patriarca, os anos 1970, é marcado pela publicação de outros romances que se reportam às ditaduras sofridas pelo continente, assim como trazem ditadores como protagonistas. Dentre eles, destacam-se o romance Yo el Supremo, escrito pelo paraguaio Augusto Roa Bastos, e a obra do cubano Alejo Carpentier, El recurso del método. De acordo com Márcia Hoppe Navarro, em Romance de um ditador, de 1989, as obras dos três latinoamericanos inauguraram uma nova vertente literária, a qual foi denominada de "romance de ditador", pois inovavam ao trazer os tiranos como protagonistas da narrativa, além de tratarem da personalidade dos mandatários.

O outono do patriarca conta a história de um ditador muito velho, que governa um país na região do mar do Caribe, de forma autoritária e cruel. Podese dizer que o livro aborda a história das ditaduras sofridas pelo continente latino-americano, que duraram longos anos, mas que ruíram.

Observa-se que a obra de García Márquez diz respeito à ruína de um governo ditatorial e de seu mandatário. A imagem do patriarca - protagonista do romance - é desconstruída desde o título do romance, pois, trata-se do "outono" desse ditador tirânico. Ao longo das páginas do livro, a imagem do protagonista vai sendo deteriorada, de forma a enfatizar tanto a decrepitude física do personagem quanto a ruína de seu governo. Esses elementos podem ser percebidos na maneira como o narrador descreve o ditador, que se converte em um homem asqueroso e vulgar, como forma de despojá-lo de sua posição elevada. São atribuídas ao patriarca características animalescas como grandes patas que se arrastam e unhas retorcidas de gavião. Assim como o homem está envelhecendo, o seu governo também está se deteriorando, como pode ser observado na metamorfose sofrida pelo palácio presidencial, que termina em ruínas, com seus móveis e tapeçarias comidos pelas vacas que invadiram o local. 
O tirano do romance é inspirado em diversos personagens históricos latino-americanos, que ocuparam o poder de diferentes nações, pois, como explica García Márquez, em Cheiro de goiaba, ele buscou “fabricar um ditador com os retalhos de todos os ditadores que tivemos na América Latina" (GARCÍA MÁRQUEZ, 2007, p. 95). O fato de o protagonista do romance não ser nomeado, sendo denominado de patriarca, reforça a intenção de se mesclar os diferentes ditadores do continente. A denominação de patriarca, dada ao protagonista do romance, não é por acaso. Ressalte-se que o ditador de García Márquez é construído a partir do conceito de dominação patriarcal, a qual, segundo Max Weber (2004), tem como germe a autoridade do chefe da comunidade doméstica, baseando-se nas relações pessoais. O poder da autoridade doméstica não tem limites impostos, sendo exercido de maneira arbitrária, sem se submeter a regras. O fundamento da estrutura patriarcal está na crença de que o chefe doméstico é uma espécie de pai, protetor do lar no qual todos mantêm com ele relações pessoais e íntimas. E, é dessa forma, que o personagem do romance de García Márquez administra o Estado, ou seja, como se tal entidade e as pessoas que a compõem fossem uma comunidade doméstica.

A obra pode ser lida como uma história do autoritarismo político vivido pela América Latina. E isso pode ser percebido pela forma como o patriarca governa o país, de modo arbitrário, torturando e assassinando os que se colocam em seu caminho. O patriarca e seu governo também parecem ser eternos, pois quando morre de morte natural a idade do ditador é indefinida, entre 107 e 232 anos. O romance aborda o "outono" desse general e a morte desse homem, que se tornou presidente da República, porque foi colocado no poder pelos estrangeiros, aludindo-se à presença do imperialismo no continente.

Em O outono do patriarca, a história é narrada por personagens, de distintos grupos sociais, e por um narrador, constituído por um "nós". No romance, a história oficial é forjada pelos "historiadores da pátria", sendo a versão do 
patriarca imposta à nação. Os relatos, que foram marginalizados e silenciados pela história oficial do governo, após a morte do patriarca e com o fim da ditadura, surgem na cena pública construindo outras histórias da pátria. Ressalte-se que o livro mostra as disputas pela memória, desnudando a narrativa histórica oficial, que justificava o poder absoluto do patriarca.

Ao discutir a questão das disputas pela memória, assim como a história oficial, é essencial fazer uma incursão pelos caminhos teóricos que relacionaram memória e história. Para isso, recorro aos textos de Michael Pollak, Hugo Achugar, Paul Ricoeur e Jacques Le Goff. De Pollak (1989) destaco a diferenciação entre as "memórias subterrâneas" e a "memória oficial", enfatizando o caráter destruidor da memória nacional. Para Hugo Achugar (2006), a questão dos usos do futuro e do passado é essencial na transmissão da memória, sendo que as narrativas, sejam elas históricas ou literárias, possuem um papel fundamental nessa mediação entre o presente, o passado e o futuro. Le Goff (2013) ressalta a relação entre a memória e o esquecimento com a história, com o poder e com as disputas entre grupos. Ricoeur (2007) salienta que a memória imposta é respaldada por uma história oficial, a qual é transmitida por meio de celebrações públicas e livros escolares.

\section{A LITERATURA, A HISTÓRIA E A MEMÓRIA}

A história pode empregar a forma narrativa para dar sentido aos acontecimentos históricos, utilizando-se de elementos, que são familiares à literatura. Ambas possuem suas relações com o ficcional, diferenciando-se pela forma como se relacionam com o mundo. A obra literária é uma fonte para a história, que no campo de possibilidades auxilia o historiador a preencher lacunas e a entender a sociedade que produziu aquela obra. A literatura pode realizar questionamentos críticos aos discursos históricos mais difundidos, 
problematizando tais discursos que são impostos, de acordo com o uso que os grupos fazem da memória. E, também, tanto a literatura quanto a história podem recuperar personagens históricos que foram marginalizados pelo discurso hegemônico de um dado período, em dada uma sociedade, propondo novas leituras do passado.

Nesse sentido, tanto história quanto literatura se relacionam com a memória e o esquecimento. As relações são imbricadas e devem ser refletidas. É importante ressaltar que discursos históricos alternativos podem suscitar novas abordagens literárias, assim como a literatura pode suscitar novas pesquisas históricas, por meio de uma perspectiva diferente ou pela abordagem de aspectos esquecidos pelo discurso histórico hegemônico.

É importante pensar que tanto a história quanto a literatura forjam/moldam/mudam imaginários nacionais nesse campo de disputas entre a memória e o esquecimento. A obra literária, assim como a obra histórica, pode reforçar ou ir contra o discurso histórico hegemônico, apresentando outros discursos. O discurso hegemônico, aqui referido, engloba as narrativas que Paul Ricoeur (2007) caracteriza como a "história oficial", ou seja, aquela que é reforçada nas escolas e celebrada publicamente, criando uma "memória autorizada". Assim, essas narrativas, que podem ser históricas ou literárias, exercem a memória e é o uso da memória que abre a possibilidade para uma manutenção ou um esquecimento. Jacques Le Goff (2013) diz que os esquecimentos e os silêncios da história são reveladores dos mecanismos de manipulação da memória coletiva e acrescento que os esquecimentos e os silêncios da literatura também são reveladores desses mecanismos, porém, ambas podem lutar contra tais esquecimentos.

Vale lembrar que tanto a obra histórica quanto a literária são produtoras de significados. Na concepção de Le Goff (2013), existem memórias que permanecem no meio social durante longos períodos, enquanto outras são 
"esquecidas". Se tanto literatura quanto história podem reforçar discursos hegemônicos, também podem estabelecer embates com esse discurso, apresentando outros discursos alternativos. Como o historiador francês Lucien Febvre (1953) ensinou, a história, como é concebida hoje, é escrita a partir das inquietações do presente, ou seja, o passado é questionado a partir do presente do historiador. A obra literária também aproxima o passado dos olhos do leitor contemporâneo, propondo leituras a partir das inquietações do presente.

Literatura e história são garantidoras da memória e do esquecimento, não sendo essas garantias estáticas, pois o surgimento de novas narrativas, seja em uma ou em outra, provocará embates, o que faz com que os significados do passado se movam e se transformem. Esse movimento possibilita que os imaginários nacionais, a respeito de grupos vencidos que foram silenciados, também mudem, bem como o significado que atribuímos a certos acontecimentos históricos.

Destaca-se como ponto essencial do romance que a história da América Latina é abordada em $\mathrm{O}$ outono do patriarca como maneira de fornecer elementos para se questionar as vertentes hegemônicas da historiografia. O patriarca é um personagem fictício, que possui características e pratica ações que diversos ditadores do continente latino-americano realizaram ao longo de tantos anos. Importante lembrar que esses tiranos, assim como os seus governos, também vivenciaram o seu "outono", chegando ao fim.

\section{O PATRIARCA E SEU REINO DE TERROR}

As ditaduras enfrentadas pela América Latina no século XX são abordadas no romance por meio de episódios que se referem a diversos tiranos latinoamericanos, tratando o poder personalista daqueles que por longos anos, detiveram o poder. No que se refere à perpetuação no poder, pode-se perceber, 
como um dos mecanismos que auxiliam nessa perduração do patriarca, a difusão, pelos denominados no romance de "historiadores da pátria", de uma imagem mitificada do ditador. Crenças populares, de que o general possuía poderes como o de cura e o de controle da natureza, também são relatadas pelo narrador.

Saliente-se que o ditador da República Dominicana, Rafael Leónidas Trujillo, atribuía a si o poder de cura de doenças, sendo que nos hospitais do país existiam placas que diziam "Só Trujillo pode curá-lo", além de outras, que agradeciam ao tirano por esse poder. Várias anedotas, referentes aos ditadores latino-americanos, podem ter servido de inspiração para $O$ outono do patriarca, como o filho de Trujillo, que foi nomeado coronel do Exército aos sete anos de idade; o anúncio da falsa morte de Juan Vicente Gómez, a fim de castigar quem se atrevesse a comemorá-la; assim como a frase dita pela mãe do tirano boliviano, Enrique Peñaranda, durante uma cerimônia, de que se soubesse que seu filho chegaria a presidente teria ensinado ele a ler e a escrever. Há, ainda, a questão da longevidade dos ditadores Juan Vicente Gómez e José Gaspar Rodríguez de Francia, que governaram seus países por longos anos, mantendo-se no poder até a morte, o que pode ter inspirado o escritor colombiano.

A respeito da violência perpetrada por governos autoritários, o tirano de O outono do patriarca sempre praticara torturas e destinara a mortes violentas os que se atrevessem a se opor ao seu governo. As formas mais utilizadas para a morte de opositores eram serem jogados a jacarés famintos, tal como fazia o ditador da República Dominicana, Rafael Leónidas Trujillo³, ou serem esquartejados por cavalos, como era praticado nos tempos coloniais. Mas, a pedido de sua esposa Leticia Nazareno, o tirano do romance aboliu o sistema de esquartejamento e "havia tentado pôr em seu lugar a cadeira elétrica que lhe havia presenteado o comandante do desembarque para que também nós desfrutássemos do mais civilizado método de matar" (GARCÍA MÁRQUEZ,

3 Sobre as histórias de ditadores que governaram a América Latina, ver Taquari (2012). 
1993, p. 180). Como os personagens relatam, sobre a cadeira elétrica, "sabíamos a hora exata do experimento mortal porque ficávamos um instante nas trevas com a respiração truncada pelo horror" (GARCÍA MÁRQUEZ, 1993, p. 180).

Mas é com a instalação do "serviço de inteligência" que o uso da violência atinge o seu auge. No romance, essa fase da ditadura é verificada no surgimento do personagem José Ignácio Sáenz de la Barra, que, segundo o narrador, era um “bárbaro vestido de príncipe” (GARCÍA MÁRQUEZ, 1993, p. 198), o que pode ser entendido como uma alusão ao refinamento das práticas de perseguição do regime, com a implantação de órgãos de informação, que baseavam-se em sistemas de delação e na repressão violenta. Nacho, como ele passa a ser denominado na obra, promete investigar a morte da esposa e do filho do patriarca, encontrando os assassinos. Instalou no país do romance, segundo o narrador, "um serviço invisível de repressão e extermínio" (GARCÍA MÁRQUEZ, 1993, p. 197), engrenado por um sistema de delação e suborno.

As cabeças, no romance de García Márquez, eram entregues no palácio presidencial com seus respectivos certificados de morte. Nacho forjava para cada morto um atestado de óbito, inventando causas para suas mortes. Estudantes, ativistas de movimentos clandestinos contra a ditadura e demais opositores tinham, em seus atestados, o registro de que teriam morrido devido a brigas em bares, acidentes banais, intoxicações ou mesmo por desenganos amorosos. Nas ditaduras latino-americanas, tornou-se prática o ocultamento da causa das mortes de torturados e assassinados em seus cárceres. Em seus atestados de óbito, outras são as causas registradas, que não o espancamento, a tortura ou o fuzilamento. Na ditadura de Rafael Leónidas Trujillo, os jornais funcionavam como porta-vozes do governo, noticiando mortes por atropelamento, que na verdade, teriam ocorrido nas câmaras de tortura do regime.

A imagem da ditadura no romance não pode ser dissociada da imagem do patriarca, que encarna a personificação do poder. Antes de seu envelhecimento, 
quando as ordens passam a ser dadas antes que ele pense em formulá-las, o poder era:

Uma torrente febril que víamos brotar ante nossos olhos dos seus mananciais primitivos, de modo que bastava que ele apontasse com o dedo as árvores que deviam dar frutos e os animais que deviam crescer e os homens que deviam prosperar, e havia ordenado que tirassem a chuva de onde estorvasse as colheitas e a pusessem em terras de estiagem, e assim havia sido, senhor, eu o vi, pois sua lenda havia começado muito antes que ele mesmo se acreditasse dono de todo o seu poder. (GARCÍA MÁRQUEZ, 1993, p. 89)

Em Cheiro de goiaba, García Márquez declara que o romance lhe deu a oportunidade de refletir sobre o poder, pois sempre acreditou que o poder absoluto era a realização mais alta e mais complexa do homem, sendo a sua grandeza e a sua miséria ao mesmo tempo. Em O outono do patriarca, o ditador acredita ser o dono de todo o seu poder, decidindo sobre o destino do país. O patriarca pergunta que horas são e lhe respondem que era a hora que ele desejava que fosse, pois o mundo só funcionava porque ele estava no comando.

Ditaduras latino-americanas como a de Rafael Leónidas Trujillo, da República Dominicana (1930-1961), Juan Vicente Gómez, da Venezuela (19081935), Manuel Estrada Cabrera, da Guatemala (1898-1920), Porfírio Díaz, do México (1876-1910), José Gaspar Rodríguez de Francia, do Paraguai (1814-1840), os Somoza, da Nicarágua (1933-1979), assim como outras, caracterizaram-se pela mitificação da pessoa do ditador, o qual era tido como a personificação do poder. Esses ditadores conduziram com mão de ferro suas nações, por longos anos, assassinando os que se opusessem à sua dominação.

No artigo "Dictadores, militares y legitimidad en América Latina", publicado em 1981, no periódico Crítica E Utopia, o cientista político francês Alain Rouquié faz uma distinção entre o modelo de ditadura romana e as ditaduras modernas, considerando estas últimas como um regime de exceção que, por circunstâncias particulares, se exerce sem controle, assim, o poder do governante 
sobre os governados não conhece nenhuma restrição, ou seja, as garantias fundamentais são abolidas. Na concepção do cientista político, as ditaduras latino-americanas fazem parte de um período histórico em que ocorreu um fenômeno continental, no qual um único ditador exerceu o poder em seu país por longos anos, o que garantiu um lugar para os "patriarcas" na memória coletiva.

Nessa perspectiva, duração e personalização de um regime de exceção são os componentes fundamentais das ditaduras latino-americanas. No romance de García Márquez, não há menção aos nomes desses ditadores históricos, mas pode-se pensar que a história desses governantes e a forma como dominaram os países, espalhando o terror nas sociedades que subjugaram, podem ter servido de inspiração para a obra.

Em O outono do patriarca, o tirano comanda o destino do país, subjugado pelo seu poder, por meio da imposição do terror. O tirano entra nas casas, sem pedir licença, provando a comida ainda no fogão. Ele manda matar os maridos das mulheres que ele deseja, para que esses não se tornem seus inimigos. Francisca Linero, personagem que é violada pelo patriarca, em uma fazenda, tem o marido assassinado por Saturno Santos, a mando do tirano. A personagem relata que:

O homem do facão levou Poncio Daza para o interior dos bananais e o retalhou em fatias tão finas que foi impossível recompor o corpo espalhado pelos porcos, pobre homem, mas não havia outro remédio, disse ele, porque seria um inimigo mortal para toda a vida. Eram imagens do seu poder que lhe chegavam de muito longe e exacerbavam-lhe a amargura do quanto lhe haviam aguado a salmoura do poder. (GARCÍA MÁRQUEZ, 1993, p. 96)

No trecho acima, podem ser verificadas as imagens de um "reino de pesadelo", como as várias vozes narrativas se referem ao governo do patriarca, em diferentes passagens do livro. Ressalte-se que o próprio general sente uma amargura pelos atos que realizou no passado, embora considere que tenham sido necessários para manter-se no poder. Essas reflexões do ditador, que é 
humanizado e tem sua consciência sendo escrutinada pelo narrador, é um dos elementos do denominado "romance de ditador".

Em O outono do patriarca, o tirano enfrentou vários momentos em que a sua cadeira fora cobiçada por outros, que disputaram o seu poder. Os últimos caudilhos ameaçavam a herança da Guerra Federal, o cargo de presidente, mas o patriarca eliminou todos eles. A descrição do palácio presidencial com os corpos dos caudilhos mortos em um lodo de sangue é uma imagem que reforça o poder centralizado do patriarca sobre o poder local.

Outro momento enfrentado pelo tirano nessa disputa por seu poder foi quando o general Rodrigo de Aguilar, homem de sua confiança, estabeleceu um sistema de poder dentro do seu poder. Quando o ditador descobre que ele planejava interná-lo em um asilo, o seu fim é ser servido em uma bandeja para os oficiais do Estado Maior. A imagem de "Rodrigo de Aguilar entrou em uma bandeja de prata posto de todo o comprimento sobre uma guarnição de couveflores e louros, macerado em temperos, dourado ao forno, enfeitado com a farda de cinco amêndoas de ouro" (GARCÍA MÁRQUEZ, 1993, p. 120) é a imagem do poder do tirano.

Quando o Exército se rebela contra o patriarca, os soldados do Quartel do Conde também são eliminados. A imagem do poder do ditador é a da carroça de leite, enviada pelo patriarca, que entra no quartel e, ao ser aberto o primeiro tonel, a carroça explode "no calor vulcânico do lúgubre edifício de argamassa amarela em que não houve jamais uma flor, cujos escombros ficaram suspensos um instante no ar com a explosão tremenda dos seis tonéis de dinamite" (GARCÍA MÁRQUEZ, 1993, p. 115). Essas são imagens do poder do patriarca, que são trazidas pelos relatos de diferentes personagens e do narrador do romance.

Mas se o poder absoluto ao mesmo tempo em que é a realização mais alta do homem é também a sua miséria, o patriarca não está isento disso. Vivendo a solidão do poder, o patriarca não confia em mais ninguém. Ao anoitecer, ele se 
tranca em um quarto com várias fechaduras que só abrem por dentro. $\mathrm{O}$ tirano isola-se de todos, pois tem uma incapacidade para o amor, tal como o coronel Aureliano Buendía, que se isolava dentro de um círculo traçado no chão. O ditador havia consultado as pitonisas e sabia que morreria no chão de seu quarto, vestido como um homem comum, e assim "havia tratado de compensar aquele destino infame com o culto abrasador do vício solitário do poder" (GARCÍA MÁRQUEZ, 1993, p. 252).

Quando o patriarca vive o seu "outono", passa a conviver com as misérias de sua glória, ou seja, com as mentiras que lhe diziam sobre como ia o governo, com a multidão que o exaltava por estar sendo coagida pelo Exército, e assim, "havia chegado sem espanto à ficção de ignomínia de mandar sem poder, de ser exaltado sem glória e de ser obedecido sem autoridade" (GARCÍA MÁRQUEZ, 1993, p. 253).

O ditador do romance vê seu reino de terror desmoronar, assim como vive a decrepitude de seu corpo. O personagem percebe que não é mais o dono de todo o seu poder e se dá conta de sua imensa solidão. O próprio patriarca, após a sua morte, tenta se justificar e contar uma versão de si mesmo e de seu governo, impondo a sua narrativa. Desse modo, o seu relato, por meio de sua voz, entrará em embate com os relatos dos outros personagens, de diferentes grupos sociais, que tiveram suas vozes marginalizadas e silenciadas. Em O outono do patriarca é possível identificar as relações entre a memória, o esquecimento, a história, a luta pelos direitos de memória e as disputas em torno da memória e da história.

\section{HISTÓRIA E MEMÓRIA EM DISPUTA}

A propósito da memória, Paul Ricoeur (2007) em A memória, a história, o esquecimento defende que não temos outro recurso, no que diz respeito à 
referência ao passado, senão a própria memória, pois ela é nosso único recurso para significar o caráter passado daquilo que declaramos nos lembrar.

Ricoeur (2007) comenta que para Santo Agostinho ${ }^{4}$ e esforço de recordação relaciona-se à ideia da luta contra o esquecimento, contra o temor de "sepultamento" no esquecimento. De acordo com Paul Ricoeur (2007), Santo Agostinho traz em seu pensamento a questão paradoxal que envolve o fato de não ser possível se referir ao esquecimento sem se lembrar desse, pois o reconhecimento daquilo que foi esquecido somente seria possível por meio da lembrança do esquecimento, ou seja, o paradoxo consiste em lembrarmos de que esquecemos algo. Desse modo, salienta Ricoeur (2007), a ideia de Santo Agostinho resulta em um enigma, segundo o qual o esquecimento seria simplesmente uma espécie de barreira que dificultaria a evocação das lembranças, ou o esquecimento seria consequência do desgaste, ocasionado pelo tempo, dos rastros dos acontecimentos que vivenciamos.

De acordo com o filósofo francês, o esquecimento continua "a ser a inquietante ameaça que se delineia no plano de fundo da fenomenologia da memória e da epistemologia da história" (RICOEUR, 2007, p. 423). Memória, história e esquecimento, segundo Ricoeur (2007), são fenômenos relativos ao passado, sendo “o passado, em sua dupla dimensão mnemônica e histórica que, no esquecimento, se perde; a destruição de um arquivo, um museu, uma cidade - esses testemunhos da história passada - equivale a esquecimento" (RICOEUR, 2007, p. 300). Paul Ricoeur (2007) comenta sobre as relações entre a história e a memória, que de um lado há a pretensão da história de reduzir a memória a um objeto, os "novos objetos" dos Annales, de outro, há a pretensão da memória coletiva de avassalar a história pelo viés dos abusos de memória, que são as comemorações impostas pelos grupos políticos que detêm o poder.

\footnotetext{
4 Ricoeur se refere à obra Confissões, escrita por Santo Agostinho no século IV.
} 
Na prática conjunta da memória e do esquecimento, segundo Paul Ricoeur (2007), importa ressaltar a questão dos usos e abusos da memória, que também envolvem o jogo entre a história e a memória. O exercício da memória é o seu uso, que abre a possibilidade para os abusos, que resultam de uma manipulação da memória e do esquecimento por detentores do poder.

Na manipulação da memória, um componente importante é a ideologia, que por meio de seu discurso justificador do poder, da dominação, mobiliza recursos de manipulação para impor suas narrativas. Assim, os detentores do poder podem se valer de narrativas para se legitimarem. As narrativas podem ser de fundação, de glória e de humilhação. De acordo com o filósofo, "a memória imposta está armada por uma história ela mesma 'autorizada', a história oficial, a história aprendida e celebrada publicamente" (RICOEUR, 2007, p. 98). No plano institucional, a memória exercida é uma memória ensinada, forçada a exercer a rememoração de acontecimentos tidos como fundadores dessa história e da identidade que a encerra. A história é ensinada e celebrada.

Saliente-se que na constituição das identidades comunitárias o perigo maior, sugere Ricoeur (2007), está no manejo da história autorizada, imposta, celebrada (a história oficial). O uso dessa narrativa pode se tornar uma armadilha quando é imposta uma narrativa canônica que despoja outros atores sociais do poder de narrarem a si mesmos, o que é uma forma de esquecimento sofrida.

Nas relações entre memória e história no romance $O$ outono do patriarca, é importante ressaltar a construção da memória nacional pelo governo. Em diversos momentos da obra, são mencionados atos comemorativos como o aniversário do dia em que o patriarca ascendeu à presidência, bem como a produção de selos e moedas, com a imagem do ditador, que podia se ver em todos os lugares. Ou seja, a imagem do tirano era insistentemente difundida, ao longo dos anos de seu governo. 
Pode-se identificar as práticas, descritas na passagem acima, como "abusos" de memória, na concepção de Todorov (2015), em Los abusos de la memoria, pois a todo o momento a população se depara com a imagem do tirano, criando uma sensação de onipresença do general em todos os lugares e na vida da população. Comemorações que celebram a ascensão do ditador à presidência, bem como seus retratos por toda parte, conformam uma imposição da narrativa do grupo político detentor do poder.

O discurso que justifica o governo do patriarca é um discurso de fundação, que celebra a sua ascensão por meio de uma narrativa que trata o período de antes dele como algo incerto e obscuro: "uma pátria que então era como tudo antes dele, vasta e incerta, até o extremo de que era impossível saber se era noite ou dia naquela espécie de crepúsculo eterno" (GARCÍA MÁRQUEZ, 1993, p. 163).

O patriarca elabora uma narrativa que justifica o seu poder, dizendo que ele havia imposto a ordem e a civilização no país. Dentre os feitos relembrados pelo patriarca, ele havia cortado as árvores das praças dos povoados, para que ninguém se enforcasse, havia proibido enterros sem caixões, e havia construído o trem dos páramos, para que nenhuma mula desbarrancasse nos abismos das serras.

No discurso do ditador, o país, antes da instauração de seu governo, era um lugar de incertezas: "pois assim eram aqueles tempos de godos em que Deus mandava mais que o governo, os maus tempos da pátria" (GARCÍA MÁRQUEZ, 1993, p. 162). Verifica-se que o ditador constrói um discurso para legitimar-se no poder como aquele que acabou com os males do país, criando um vínculo entre o seu governo e a ordem.

Porém, o narrador do romance relata atos cometidos pelo patriarca, que deslegitimam o seu governo. Esse narrador, que abarca uma pluralidade de vozes, desnuda os crimes do ditador e traz à cena outras narrativas sobre o 
patriarca. Além de vários atos ilícitos cometidos ao longo de seu governo, somam-se as atrocidades perpetradas pelo patriarca, que são relatadas pelos diferentes personagens, que definem o governo do tirano como seu reino de pesadelos.

A imagem do patriarca, difundida insistentemente no país, segundo o narrador, não corresponde à daquele homem, encontrado morto na casa do poder. Essa percepção do narrador também pode ser entendida como um desnudamento da construção da imagem do ditador. Segundo o narrador, nos meios de comunicação do país, "poucos jornais que ainda se publicavam continuavam consagrados a proclamar sua eternidade e a falsificar seu esplendor com material de arquivo" (GARCÍA MÁRQUEZ, 1993, p. 121). O narrador relata como eram as descrições do patriarca nas cartilhas escolares:

As descrições de seus historiadores ficavam-lhe grandes, pois os textos oficiais das cartilhas referiam-no como um patriarca de tamanho descomunal que nunca saía de sua casa porque não cabia pelas portas, que amava as crianças e as andorinhas, que conhecia a linguagem de alguns animais, que tinha a virtude de antecipar-se os desígnios da natureza, que adivinhava o pensamento simplesmente olhando nos olhos e conhecia o segredo de um sal eficaz para curar as marcas dos leprosos e fazer andar os paralíticos. (GARCÍA MÁRQUEZ, 1993, p. 48)

A tentativa de manipulação da memória no romance pode ser percebida também pelas descobertas do padre Demétrio Aldous, quando investigava o passado da mãe do ditador para canonizá-la. O padre descobriu que o ditador havia forjado provas da santidade de sua mãe e de que ele possuía três certidões de nascimento, "sendo três vezes abortado graças aos artífices da história pátria que haviam emaranhado os fios da realidade para que ninguém pudesse decifrar o segredo de sua origem" (GARCÍA MÁRQUEZ, 1993, p. 143).

A memória oficial do país foi forjada pela ditadura, por "seus historiadores", como denomina o narrador, que criaram a imagem de um ditador grandioso, que possuía poderes sobrenaturais de cura. Essa memória forjada é 
uma memória imposta, pois, como o patriarca dizia, "não interessava que uma coisa de então não fosse verdade, que porra, com o tempo será" (GARCÍA MÁRQUEZ, 1993, p. 161).

Em relação à construção de uma memória oficial no romance, deve-se retomar o que disse Paul Ricoeur (2007), em A memória, a história, o esquecimento, de que a memória imposta está respaldada por uma história oficial, a história "autorizada", que será transmitida e celebrada. Ainda, a imposição de uma "narrativa canônica", como sugeriu Ricoeur (2007), despoja outros atores sociais do poder de narrarem a si mesmos e de constituírem suas identidades.

Em O outono do patriarca, pode ser observado que tais atores sociais despojados de narrarem a si mesmos, suas histórias e suas memórias, durante o período do governo tirânico do patriarca, com a morte do ditador, insurgem na cena formando um coletivo de vozes, que constituem o romance. No artigo intitulado "Memória, esquecimento, silêncio", traduzido e publicado em 1989 no periódico Estudos Históricos, o sociólogo Michael Pollak aborda a memória coletiva, pensando os processos e os atores que interferem na constituição e na formalização das memórias. O pesquisador se apoia na história oral, que busca analisar os excluídos, os marginalizados e as minorias, ressaltando como as "memórias subterrâneas", que seriam as memórias desses grupos excluídos da "memória oficial," divergem desta. Pollak (1989) enfatiza o caráter de destruição, de uniformização e de opressão da memória coletiva de cunho nacional. Assim, segundo o sociólogo, as "memórias subterrâneas", que trabalham de forma silenciosa, sendo passadas entre as gerações, podem vir à tona em momentos de crise, o que provoca uma disputa entre as memórias.

De acordo o autor, nos momentos de mudanças críticas na história, as memórias subterrâneas, tidas como proibidas e clandestinas, emergem trazendo consigo ressentimentos acumulados ao longo do tempo e contra uma memória da dominação. Quando tais memórias marginalizadas invadem a cena pública 
suas reivindicações também se agregam à disputa entre as memórias que emergiram. Para ele, "o longo silêncio, longe de conduzir ao esquecimento, é a resistência que uma sociedade civil impotente opõe ao excesso de discursos oficiais" (POLLAK, 1989, p. 3). Ele ressalta que essas relações podem ocorrer tanto entre Estado e sociedade civil, quanto entre a sociedade civil como um todo e os grupos minoritários. Pollak (1989) aborda diversos exemplos de "memórias subterrâneas" que sobreviveram, sendo transmitidas por familiares, por redes de sociabilidade ou por associações e que, ao retornarem ao espaço público, colocaram em xeque a memória oficial forjada.

Michael Pollak (1989), apoiando-se nas considerações do historiador Henry Rousso, explica que na organização da memória coletiva são definidos e reforçados os sentimentos de pertencimento a uma dada coletividade, sendo que as referências a um passado comum servem para manter a coesão dos grupos e definir o lugar desses grupos, ou seja, fornece-se um quadro de referências ao grupo. Esse procedimento é definido como "memória enquadrada", assim, há um trabalho de enquadramento da memória em que se forjam imagens de grupos. O material da história serve como fonte para o processo de enquadramento, sendo selecionado e interpretado, combinando-se a outras referências existentes, num trabalho em que a meta é manter as fronteiras sociais e, também, incluir as disputas da memória, reinterpretando o passado de forma a produzir discursos coerentes. Nesse sentido, aqueles que não se reconhecerem nessa imagem não irão desenvolver um sentimento de pertencimento ao grupo, abalando sua identidade individual.

Os rastros do trabalho de enquadramento são a produção de discursos sobre eventos e personagens, bem como o patrimônio material respaldado por leis e decretos, produtos culturais como filmes de ficção, filmes-testemunho e documentários. Segundo Pollak (1989), tal trabalho de enquadramento provoca um rearranjo da memória coletiva, o que é essencial para manter a perenidade 
das estruturas da sociedade. Mas as memórias deixadas às margens do enquadramento podem ser minimizadas ou até eliminadas pela memória coletiva, nesse momento, a imagem oficial do passado entrará em conflito com as lembranças individuais. Pollak (1989) explica que a prática da história oral possibilita a reconstrução de histórias de vida e de identidades, levando o indivíduo a redefinir o seu lugar dentro de uma dada sociedade, uma vez que essa metodologia provoca uma reflexão sobre a questão de falar sobre o seu passado, pois descortina um trabalho de gestão da memória.

As vozes em O outono do patriarca relatam suas lembranças sobre o ditador e seu governo, a forma como ele dispunha das pessoas, como decidia o destino dos cidadãos da pátria segundo as suas vontades. Ressalte-se que García Márquez recorreu à oralidade ao construir as vozes em O outono do patriarca. Entende-se que a falta de identificadores, como aspas ou travessões, bem como pontos finais e parágrafos, ocorre devido a uma necessidade de se criar um efeito de várias vozes numa conversa, na qual cada voz evidencia o seu ponto de vista. Assim, a cada momento, ouve-se uma voz diferente que se destaca. O fluir dessas vozes, como se estivessem diante de alguém contando o que se passou, numa conversa, permite dizer que García Márquez se utiliza de fontes orais nesse livro.

Observa-se que, após a morte do patriarca, várias pessoas desejam relatar o que se passou durante aquele governo sombrio e opressor. Assim, propõe-se neste artigo que a insurgência dessas vozes na cena pública, que desejam relatar as suas memórias silenciadas, reprimidas durante a ditadura, são "memórias subterrâneas", tal como proposto por Pollak (1989). Pois essas memórias sobreviveram no subterrâneo para virem à tona no momento em que a ditadura termina.

Assim, com o fim do governo do patriarca, instaura-se um vazio de legitimidade que corresponde à velha ordem, o que exige que haja pronunciamentos que legitimem o estabelecimento de uma nova ordem. Desse 
modo, na esteira das considerações do crítico uruguaio Hugo Achugar (2006), na obra Planetas sem boca, a memória organiza relatos e histórias, ela está presente nas preocupações acerca da transmissão do que estava esquecido ou silenciado. A investigação do passado é uma forma de recuperar ou corrigir a memória. Segundo o crítico, os usos do futuro e do passado são centrais na transmissão da memória, seja a memória do passado ou do presente, sendo isso o que ocorre em toda narrativa histórica ou ficcional. Assim, a memória deve ser considerada como mediadora do passado, do presente e do futuro, viva e diferente de qualquer outro arquivo.

Hugo Achugar (2006) utiliza-se de Hamlet para formular a ideia de "direitos de memória", pois, com a morte do protagonista, Horácio é encarregado de relatar a sua história, mas Fortinbrás reivindica seus direitos de memória sobre o reino. No caso da peça de Shakespeare está ocorrendo a passagem de um reino a outro, já o crítico uruguaio se refere aos processos de independência da América Latina. Ele também salienta que esse fenômeno ocorre em situações de encerramento de tempos históricos e modos de organização, citando o momento da pós-ditadura. Assim, na passagem da velha para a nova ordem, produz-se um vazio de legitimidade, que deve ser preenchido em função da nova situação gerada, pressupondo uma releitura e uma reconstrução através de uma nova narrativa.

No sentido apreendido por Hugo Achugar (2006), grupos antes silenciados insurgem na cena político-social em busca de revisar o passado como formas de uso do presente e do futuro, lutando para exercerem o direito de constituir a memória de seu país, reagindo contra o esquecimento. Desse modo, em $O$ outono do patriarca, observa-se que as "memórias subterrâneas", dos personagens que vivenciaram o governo do patriarca, buscam revisar esse passado, ou seja, o período ditatorial, pois há um vazio de legitimidade da velha ordem. Essas vozes relatam sobre o patriarca e o terror instaurado no país, 
denunciando as atrocidades do ditador e a venda de recursos naturais a nações estrangeiras. Essas vozes, ao relatarem suas lembranças buscam exercer o seu "direito de memória", o direito de contarem outras histórias sobre a pátria, diferente da história e da memória oficial imposta pelo governo.

Memória e poder estão imbricados nas relações que se estabelecem com os usos que os grupos fazem do passado e do futuro, na concepção de Le Goff (2013). Os usos da memória e do esquecimento se configuram como instrumentos de poder de grupos ou indivíduos, pois há aquelas memórias que permanecem no meio social durante longos períodos, enquanto outras são "esquecidas", silenciadas, soterradas. História, memória e esquecimento se relacionam nos momentos de disputas, já que o vencedor terá sua memória perpetuada na história, silenciando e fazendo com que seja esquecida a memória do vencido. Nesse sentido, "assim como a cultura não é isenta de barbárie, não o é, tampouco, o processo de transmissão da cultura" (BENJAMIN, 1994, p. 225). Walter Benjamin (1994) aconselha ao materialista histórico que se desvie e escove a história a contrapelo, escavando a partir do presente, outras histórias, outras experiências do passado, dotando-as de sentido.

Na esteira da discussão das relações da memória com o poder, vale retomar o que disse o historiador Jacques Le Goff:

\begin{abstract}
A memória coletiva foi posta em jogo de forma importante na luta das forças sociais pelo poder. Tornarem-se senhores da memória e do esquecimento é uma das grandes preocupações das classes, dos grupos, dos indivíduos que dominaram e dominam as sociedades históricas. Os esquecimentos e os silêncios da história são reveladores desses mecanismos de manipulação da memória coletiva. (LE GOFF, 2013, p. 390)
\end{abstract}

No romance $O$ outono do patriarca, além das vozes, antes silenciadas, que reivindicam os seus direitos de memória com o fim do regime, há a voz do patriarca morto, que deseja impor a sua versão sobre o seu governo. Assim, o romance, além de ser composto por várias vozes, antes silenciadas, também 
abarca a voz do patriarca e dos historiadores da pátria, que forjam uma memória oficial. Essas vozes entram em embate, configurando uma disputa de memórias. Isso pode ser percebido pela forma dialógica que prevalece no romance. Como dito anteriormente, no romance $\mathrm{O}$ outono do patriarca, há a voz do patriarca, de outros personagens e de um narrador que utiliza o pronome "nós". A voz desse narrador abarca outras vozes que aparecem ao longo do livro, levando a um embate de vozes, que possuem orientações discursivas divergentes. As vozes da obra se encontram e interagem, em uma relação permeada por tensões.

Na esteira do que disse Le Goff (2013), uma das grandes preocupações daqueles que dominam/dominaram as sociedades históricas é serem os senhores da memória e do esquecimento. Nesse sentido, observa-se no romance de García Márquez que a disputa em torno da memória, entre o patriarca morto e as vozes antes silenciadas por ele e seu governo, pode ser entendida como a relação entre a memória e o esquecimento com a história, com o poder e com as disputas entre grupos.

\section{CONCLUSÃO}

Considerando o que disse Jacques Le Goff (2013), na obra História e memória, os esquecimentos e os silêncios impostos são reveladores dos mecanismos de manipulação da memória coletiva. Sob essa perspectiva, observase que o romance de García Márquez, por meio das vozes narrativas, propicia que haja o desnudamento dos mecanismos de manipulação da memória, quando o narrador confronta a imagem do patriarca com o homem que é encontrado no palácio e quando narra os atos ilícitos e as atrocidades cometidas pelo tirano. Dessa forma, se existem narrativas que servem para legitimar o poder, também existem as que servem para desvelar o poder. Quando morre o patriarca e com 
ele tem fim a ditadura de longos anos, outras narrativas sobre o país surgem, colocando em xeque a história forjada pelo governo do patriarca.

As vozes do romance $O$ outono do patriarca constroem outras narrativas históricas. Os relatos dos personagens sobre o governo podem ser relacionados ao contexto dos fins das ditaduras no continente, momento em que surgem várias narrativas sobre os países latino-americanos, histórias contadas por grupos, silenciados e marginalizados, que reivindicam o direito de narrarem outras histórias de suas pátrias.

Vale retomar a expressão “direitos de memória”, de Hugo Achugar (2006), para compreender que o romance é construído com base na reivindicação dos personagens em relatar outra(s) história(s) da pátria, diferentes da oficial. A expressão "direitos de memória" está relacionada aos direitos que os diferentes habitantes da América Latina possuem de constituir as memórias de seus países, revisando-as, pois é fundamental lembrar que as memórias estão em constantes disputas. A obra de García Márquez demonstra essas disputas tanto em sua forma de construção - por meio das vozes que entram em embate e se confrontam -, quanto pela desconstrução que o narrador empreende ao longo do romance, como uma forma de despojar o ditador morto de sua autoridade e glória. Ao final do romance, percebe-se que, com a morte do patriarca, nada lhe restará, e que ele se tornará apenas uma lembrança longínqua na memória da nação.

Importante ressaltar que o romance coloca a questão das disputas pela memória, mostrando seus desnudamentos e seus encobrimentos, bem como sua relação com o poder, o que leva o leitor à reflexão de que as narrativas sobre o passado não são definitivas.

Por fim, destaca-se que este artigo não entende o texto de Gabriel García Márquez como reflexo da história, mas se buscou, ao longo de seu desenvolvimento, evidenciar como o escritor colombiano, valendo-se de fontes históricas, personagens, vozes e perspectivas, forneceu elementos para o 
questionamento de uma versão única da história latino-americana e mostrou a necessidade do não esquecimento dos fatos renegados por uma vertente da historiografia.

\section{REFERÊNCIAS}

ACHUGAR, Hugo. Planetas sem boca: escritos efêmeros sobre arte, cultura e literatura. Tradução de Lyslei Nascimento. Belo Horizonte: Editora UFMG, 2006.

BENJAMIN, Walter. Magia e técnica, arte e política: ensaios sobre literatura e história da cultura. Tradução Sérgio Paulo Rouanet. 7 ed. São Paulo: Brasiliense, 1994. (Obras escolhidas; v.1).

FEBVRE, Lucien. Combats pour l'histoire. Paris: Armand Colin, 1953.

GARCÍA MÁRQUEZ, Gabriel. Cheiro de goiaba: conversas com Plinio Apuleyo Mendonza. Tradução de Eliane Zagury. 6. ed. Rio de Janeiro: Record, 2007.

GARCÍA MÁRQUEZ, Gabriel. O outono do patriarca. Tradução de Remy Gorga, Filho. 13. ed. Rio de Janeiro: Record, 1993.

LE GOFF, Jacques. História e memória. Tradução de Bernardo Leitão [et al.]. 7 ed. Campinas: Editora da Unicamp, 2013.

POLLAK, Michael. Memória, esquecimento, silêncio. In: Estudos Históricos, Rio de Janeiro, vol. 2, no 3, 1989.

RICOEUR, Paul. A memória, a história, o esquecimento. Tradução de Alain François [et al.]. Campinas, SP: Editora da UNICAMP, 2007.

ROUQUIE, Alain. Dictadores, militares y legitimidad en America Latina. In: Crítica $\mathcal{E}$ Utopía. Latinoamericana de Ciencias Sociales, Buenos Aires, n. 5, septiembre de 1981.

TAQUARI, Carlos. Tiranos e tiranetes: a ascensão e queda dos ditadores latinoamericanos e sua vocação para o ridículo e o absurdo. 3. ed. Rio de Janeiro: Civilização Brasileira, 2012.

TODOROV, Tzvetan. Los abusos de la memoria. Traducción de Miguel Salazar. Barcelona: Paidós, 2015.

TORRE, Michelle Márcia Cobra. Transculturação e dialogismo/pátria, nação e memória em O outono do patriarca. 2011. 110 f. Dissertação (Mestrado em Estudos Literários). Faculdade de Letras, Universidade Federal de Minas Gerais, Belo Horizonte.

WEBER, Max. Economia e sociedade. Tradução de Regis Barbosa e Karen Elsabe Barbosa. 2 v. Brasília, DF: Editora Universidade de Brasília: São Paulo: Imprensa Oficial do Estado de São Paulo, 2004.

Nota do editor:

Artigo submetido para avaliação em: 19 de março de 2021.

Aprovado em sistema duplo cego em: 28 de julho de 2021. 